\title{
HERDING IN TURKEY DURING THE GLOBAL FINANCIAL CRISIS
}

\section{DOI: 10.17261/Pressacademia.2021.1511 \\ PAP- V.14-2021(37)-p.139-143}

\section{Melike Cobandag ${ }^{1}$, Jale Sozer Oran ${ }^{2}$}

${ }^{1}$ Marmara University, Department of Business Administration, Istanbul, Turkey. melikecobandag@marun.edu.tr, ORCID: 0000-0002-8020-6783

${ }^{2}$ Marmara University, Department of Business Administration, Istanbul, Turkey. jaleoran@marmara.edu.tr, ORCID: 0000-0001-8976-2893

To cite this document

Cobandag, M., Oran, J. S., (2021). Herding in Turkey during the global financial crisis. PressAcademia Procedia (PAP), 14, 139-143.

Permanent link to this document: http://doi.org/10.17261/Pressacademia.2021.1511

Copyright: Published by PressAcademia and limited licensed re-use rights only.

\section{ABSTRACT}

Purpose- The purpose of this study is to give evidence on herding behavior in Turkey during the global financial crisis of 2007-2009. In this study, we want to see if herding behavior is observed in Borsa Istanbul during the period when an unexpected event happened in the market. During crisis periods, investors usually follow the market consensus rather than their own mind and therefore it is more possible to detect herding behavior during crisis periods (Christie and Huang, 1995). Accordingly, we will try to calculate herding behavior statistics using the number of trades by institutional investors in the BIST30 index in Borsa Istanbul for each month between October 2008 and November 2009 which is the time period that the global financial crisis showed its effect in Turkey.

Methodology-This study employs the methodology developed by Lakonishok, Shleifer, and Vishny (hereafter LSV) (1992) in order to measure herding behavior. The statistical measure developed by LSV (1992) tries to detect whether investors in a stock exchange are inclined to stay together on the buy side or on the sell side of a given stock in a given time period. In order to measure herding behavior in Turkey, we use the number of trades by institutional investors for each stock in each month between October 2008 and November 2009 in the BIST30 index. The data was gathered from the Central Securities Depository of Turkey.

Findings- The analysis of this study reveals that the herding behavior statistic for the global financial crisis period is $1.42 \%$ in Turkey. $1.42 \%$ implies that if the possibility of a buy or sell in the market is $50 \%$, then $51.42 \%$ of institutional investors were changing their trades in one direction and $48.58 \%$ in the other direction. The herding measure of LSV (1992) in their study was $2.7 \%$, and the authors concluded that this is a small measure of herding behavior and that there is no significant evidence of herding among pension fund managers that they analyzed. Similarly in our study we find a small measure of herding as $1.42 \%$ and it is possible for us to say that there is a small evidence of herding practiced by institutional investors in Turkey during the global financial crisis of 2007-2009.

Conclusion- Based upon the findings of the analysis, it may be concluded that during the global financial crisis, there was a small evidence of herding practiced by institutional investors in Turkey. As the literature about herding behavior indicates, in crisis periods, investors usually prefer to follow the common information in the stock market rather than their own mind. According to our findings there is a small herding behavior statistic for the global financial crisis period in Turkey. We can say that the global financial crisis did not lead to a very high level of herding behavior in Borsa Istanbul. Further studies can calculate herding behavior statistics for other crisis terms in order to be able to generalize this result that there is a small evidence of herding practiced by institutional investors in Turkey during financial crisis periods.

Keywords: herding behavior, LSV measure, global financial crisis

JEL Codes: G40, G01

\section{INTRODUCTION}

The global economy faced a great recession during the global financial crisis of 2007-2009 since the Great Depression of 1929 . The bubble in the sub-prime mortgage industry was burst in the United States and it spread across to global financial institutions. Due to securitization, the sub-prime risk was distributed to many institutional investors around the world (Brigham and Ehrhardt, 2017). In Turkey, because of the global financial crisis, GDP growth rates turned into negative in October 2008 and again in October 2008 return of the BIST30 index decreased by $50 \%$ compared to October 2007 
The purpose of this study is to give evidence on an important behavioral finance issue that is herding behavior. We will try to give evidence on herding behavior in Turkey during the global financial crisis of 2007-2009. Herding behavior can be called as an irrational behavior that investors behave in similar directions at the same time in their buy or sell trades in the stock market (Wermers, 1999). In this study, we want to see if herding behavior is observed in the Turkish stock market during a period when an unexpected event happened in the market. During crisis periods, investors usually follow the market consensus rather than their own mind and therefore it is more possible to detect herding behavior during crisis periods (Christie and Huang, 1995). Accordingly we want to analyze herding behavior in Turkey during the global financial crisis. It is important to measure herding behavior because if there is a high level of herding behavior in the stock market, it can have a significant impact on stock prices and it may lead to volatility in the stock market. And also, it is important to see if herding is even higher during a financial crisis period in the stock market. In other words, it is important to see if a financial crisis triggers herding behavior in a stock market.

The share of institutional investors is getting higher in the stock markets and a large portion of investors in Borsa Istanbul are institutional investors as well. Accordingly it is important to show herding practiced by institutional investors. We will analyze herding behavior of institutional investors in our study. We will try to calculate herding statistics for each month using the number of trades by institutional investors in the BIST30 index in Borsa Istanbul between October 2008 and November 2009 which is the time period that the global financial crisis showed its effect in Turkey. October 2008 is the time that the monetary easing was started by the central bank and the time that the GDP growth rate turned into negative in Turkey. On the other hand, November 2009 was the last month of monetary easing by the central bank and the GDP growth rate turned into positive in the fourth quarter of 2009 in Turkey. Therefore, the analysis period regarding the global financial crisis in Turkey is determined as the period between October 2008 and November 2009 for this study. Furthermore, BIST30 is the stock index in Borsa Istanbul that includes the stocks with highest market value and the highest trading volume. We will consider the BIST30 stocks in our study, because as stated by Bikhchandani and Sharma (2001) it is more likely to detect herding behavior when the investments in a special group of stocks are analyzed.

In the following sections, first we will review the literature on herding behavior. Secondly, we will describe our data and the methodology of our study in detail. Lastly, we will present our findings and in section 5 we will conclude the study.

\section{LITERATURE REVIEW}

Efficient markets theory states that investors are rational in using public information. However, according to behavioral finance, investors do not always behave fully rational (Hirshleifer, D., 2015). Behavioral finance is a broader framework than efficient markets theory that it includes aspects from psychology and sociology (Shiller, 2003).

Herding behavior is an important behavioral issue to be considered under behavioral finance theory. Herding can be defined as "a group of investors trading in the same direction over a period of time" (Nofsinger and Sias, 1999). In other words we can say that investors can sometimes buy or sell the same stocks at the same time (Wermers, 1999). This can be called as herding behavior of investors and this cannot be explained by traditional finance that information is added to stock prices. This situation can rather be explained by behavioral finance.

Bikhchandani and Sharma (2001) state that "herding behavior can be unintentional or intentional". When investors use similar information in their investment decisions, it is possible to see unintentional herding. However, if investors intentionally behave in the same way as the other investors, this would not be a rational behavior and it can be said that intentional herding is seen in the stock market (Bikhchandani and Sharma, 2001)

LSV (1992) state that investors are active traders in the stock market that their buy or sell actions can have an effect on stock prices. As stated by Bikhchandani and Sharma (2001), "herding behavior can increase volatility, destabilize markets and increase the fragility of the financial system". The number of institutional investors in the stock markets has grown rapidly in the past years. Today they have a significant role in the capital markets and their trading behavior can have an important impact on stock prices. Therefore it is important to analyze the trading behavior of institutional investors.

Considering empirical studies that focus on investors' herding behavior, we can first state the study by LSV (1992). The authors used "quarterly portfolio holdings data of 341 pension fund managers in the Unites States" and they find very small evidence of herding among pension fund managers. Other important empirical studies that use LSV methodology to measure herding behavior in the United States are made by Grinblatt et al. (1995) and Wermers (1999). Grinblatt et al. (1995) and Wermers (1999) also found small evidence of herding analyzing the mutual funds. Some other studies conducted LSV (1992) methodology to calculate herding statistics in the European countries. Wylie (2005) analyzed herding among mutual fund managers in the United Kingdom by using the portfolio holdings of 268 United Kingdom mutual funds of equity. The author also conducted studies to test the accuracy of the LSV (1992) methodology. At the end of the study, Wylie (2005) stated that there is a significant amount of herding among fund managers in both the "largest and smallest stocks of the United Kingdom". Walter and Weber (2006) found evidence of herding behavior analyzing the German mutual funds. They further stated that this herding is mainly an unintentional type of herding. Voronkova and Bohl (2005) analyzing the investors in pension funds in Poland calculated herding using the LSV (1992) methodology and found evidence of herding behavior, but they also stated that this herding does not significantly impact stock prices.

Furthermore, Christie and Huang (1995) stated that it is more possible to detect herding behavior in the periods when higher stress is observed in the stock market. During volatile periods, investors are more prone to follow the other investors in the stock market rather than behaving according to their own mind. Moreover, Balcilar and Demirer (2015) applied the herding measure of Chang et al. (2000) in order to measure herding behavior in Borsa Istanbul and they find "evidence consistent with herding behavior during both the high and extreme 
volatility regimes". Accordingly, we think that herding behavior statistics could be higher in the financial crisis periods and we wanted to analyze herding by institutional investors in Turkey during the global financial crisis of 2007-2009.

\section{DATA AND METHODOLOGY}

This study employs the methodology developed by LSV (1992) in order to measure herding behavior. The statistical measure developed by LSV (1992) tries to detect whether investors in a stock exchange are inclined to stay together on the buy side or on the sell side of a given stock in a given time period.

In order to measure herding behavior in Turkey, we use the number of trades by institutional investors for each stock in each month between October 2008 and November 2009 in the BIST30 index of Borsa Istanbul. The data for this study is gathered from the Central Securities Depository of Turkey.

Following LSV (1992), our herding measure $H_{s m}$ for a given stock $\mathrm{s}$ in a given month $\mathrm{m}$, equals to;

$$
H_{s m}=\left|\frac{b_{s m}}{n_{s m}}-p_{m}\right|-\mathrm{E}\left[\left|\frac{b_{s m}}{n_{s m}}-p_{m}\right| ; b_{s m} \sim B\left(p_{m}, n_{s m}\right)\right]
$$

In the equation stated above, $b_{s m}$ shows the number of investors who are buyers of stock $\mathrm{s}$ in month $\mathrm{m}$. Total transactions in stock $\mathrm{s}$ during month $\mathrm{m}$ is indicated as $n_{s m}$. $p_{m}$ is the expected probability of a buy transaction. It is computed by dividing the total number of buys to total number of buy and sell transactions in each month. Therefore, there is a different $p_{m}$ value for each month.

The second part of the equation stated above is the expected value of the first part of the equation. Buy transactions are binomially distributed. They have the probability of $p_{m}$ and independent draws of $n_{s m}$ (Frey et al., 2014).

The above stated equation finally shows us the herding measure. As the herding measure gets higher, we can state that the herding behavior is higher. The herding measure for the whole period is the average of the herding measures calculated for each month.

\section{FINDINGS}

The share of institutional investors among all investors in Borsa Istanbul is higher than the share of individual investors. The herding behavior of institutional investors can have a significant impact on stock prices and it may lead to volatility in stock prices. Therefore, it is important to detect herding practiced by institutional investors. In this study we want to show herding statistics of institutional investors in Borsa Istanbul during the period when the effect of the global financial crisis of 2007-2009 was felt in Turkey. For this reason, we analyzed the October 2008-November 2009 period. The following figures show the share of investors in Borsa Istanbul in the years 2008 and 2009.

Figure 1: Share of Investors in Borsa Istanbul in 2008

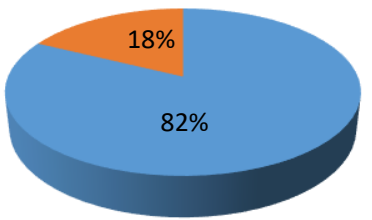

institutional investors

individual investors

Source: Central Securities Depository of Turkey

As it can be observed from Figure 1 above, in 2008 the share of institutional investors was $82 \%$ in Borsa Istanbul.

Figure 2: Share of Investors in Borsa Istanbul in 2009

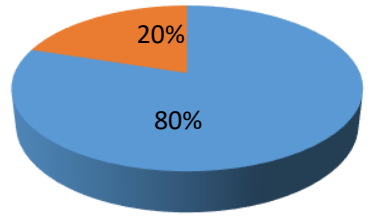

institutional investors

individual investors

\section{Source: Central Securities Depository of Turkey}

In 2009 , the share of institutional investors was $80 \%$ as the Figure 2 above shows. As the percentages indicate, institutional investors dominate the market. If a significant evidence of herding behavior is detected among institutional investors during these periods, it can be 
an indicator of future volatility of stock prices and it requires necessary actions to be taken (Bikhchandani and Sharma, 2001). Furthermore, it can show us the possibility that a financial crisis can trigger herding behavior of investors in a stock market.

The following Table 1 shows the results of our analysis. As it can be observed from the table, the herding statistic for the global financial crisis period is $1.42 \%$ in Turkey. $1.42 \%$ implies that if the possibility of a buy or sell in the market is $50 \%$, then $51.42 \%$ of institutional investors were changing their trades in one direction and $48.58 \%$ in the other direction. The herding measure of LSV (1992) in their study was $2.7 \%$, and the authors concluded that this is a small measure of herding and that there is no significant evidence of herding among pension fund managers that they analyzed. Similarly in our study we find a small measure of herding as $1.42 \%$ and it is possible for us to say that there is a small evidence of herding practiced by institutional investors in Turkey during the global financial crisis of 2007-2009.

\section{Table 1: Herding Statistic during the Global Financial Crisis in Turkey}

\begin{tabular}{|c|c|}
\hline Herding Statistic & October 2008-November 2009 \\
\hline average & $1.42 \%$ \\
\hline standard error & 0.0022 \\
\hline
\end{tabular}

\section{CONCLUSION}

Based upon the findings of the analysis of this study, it may be concluded that during the period when the effect of the global financial crisis was felt in Turkey which is the period between October 2008 and November 2009, there was a small evidence of herding practiced by institutional investors. The possibility of detecting herding behavior may be stronger when there is higher stress in the stock market compared to normal periods and when there is unexpected flow of information and volatility. In crisis periods, investors usually prefer to follow the common information in the stock market rather than their own mind. According to our findings, there is a small herding behavior statistic for the global financial crisis period in Turkey. We can say that the global financial crisis did not lead to a very high level of herding behavior in Borsa Istanbul. Further studies can calculate herding behavior statistics for other crisis terms in order to be able to generalize this result that there is a small evidence of herding practiced by institutional investors in Turkey during financial crisis periods.

\section{REFERENCES}

Angela-Maria, F., Maria, P. A., \& Miruna, P. M. (2015). An empirical investigation of herding behavior in CEE stock markets under the global financial crisis. Procedia Economics and Finance, 25, 354-361.

Balcilar, M., \& Demirer, R. (2015). Effect of global shocks and volatility on herd behavior in an emerging market: Evidence from Borsa Istanbul. Emerging Markets Finance \& Trade, 51, 140-159.

Bikhchandani, S., \& Sharma, S. (2001). Herd behavior in financial markets. IMF Staff Papers, 47(3), 279-310.

Brigham, E. F., \& Ehrhardt, M. C. (2017). Financial management: theory \& practice. Cengage Learning (Chapter 1).

Central Bank of the Republic of Turkey (CBRT) (2008). Financial stability report. 7, November.

Central Bank of the Republic of Turkey (CBRT) (2009). Financial stability report. 8, May.

Chang, E. C., Cheng, J. W., \& Khorana, A. (2000). An examination of herd behavior in equity markets: An international perspective. Journal of Banking \& Finance, 24(10), 1651-1679.

Christie, W. G., \& Huang, R. D. (1995). Following the pied piper: Do individual returns herd around the market? Financial Analysts Journal, 51(4), 31-37.

Dalgıç, N., Ekinci, C., \& Ersan, O. (2019). Daily and intraday herding within different types of investors in Borsa Istanbul. Emerging Markets Finance \& Trade, 1-18.

Demirer, R., \& Kutan, A. M. (2006). Does herding behavior exist in Chinese stock markets? Journal of International Financial Markets, Institutions and Money, 16(2), 123-142.

Frey, S., Herbst, P., \& Walter, A. (2014). Measuring mutual fund herding-a structural approach. Journal of International Financial Markets, Institutions and Money, 32, 219-239.

Grinblatt, M., Titman, S., \& Wermers, R. (1995). Momentum investment strategies, portfolio performance, and herding: A study of mutual fund behavior. The American Economic Review, 85(5), 1088-1105.

Hirshleifer, D. (2015). Behavioral finance. Annual Review of Financial Economics, 7, 133-159.

https://www.mkk.com.tr/tr-tr/Veri-Depolama-Hizmetleri/e-VERi/Sayfalar/Yillik-Istatistiki-Veriler.aspx

Lakonishok, J., Shleifer, A., \& Vishny, R. W. (1992). The impact of institutional trading on stock prices. Journal of Financial Economics, 32(1), 23-43.

Mishkin, F. S. (2009). Is monetary policy effective during financial crises?. NBER Working Paper, No: 14678. 
Nofsinger, J. R., \& Sias, R. W. (1999). Herding and feedback trading by institutional and individual investors. The Journal of Finance, 54(6), 2263-2295.

Shiller, R. J. (2003). From efficient markets theory to behavioral finance. Journal of economic perspectives, 17(1), 83-104.

Sias, R. W. (2004). Institutional herding. The Review of Financial Studies, 17(1), 165-206.

Voronkova, S., \& Bohl, M. T. (2005). Institutional traders' behavior in an emerging stock market: Empirical evidence on polish pension fund investors. Journal of Business Finance \& Accounting, 32(7-8), 1537-1560.

Walter, A., \& Weber, F. M. (2006). Herding in the German mutual fund industry. European Financial Management, 12(3), 375-406.

Wermers, R. (1999). Mutual fund herding and the impact on stock prices. The Journal of Finance, 54(2), 581-622.

Wylie, S. (2005). Fund manager herding: A test of the accuracy of empirical results using U.K. data. Journal of Business, 78(1), 381-403. 